\title{
Micromorphological and microchemical indicators of pedogenesis in Ornithogenic Cryosols (Gelisols) of Hope Bay, Antarctic Peninsula
}

\author{
Thiago T.C. Pereira ${ }^{\text {a,* }}$, Carlos Ernesto G.R. Schaefer ${ }^{\text {a }}$, João C. Ker ${ }^{\text {a }}$, Cecília C. Almeida ${ }^{\text {a }}$, Ivan C.C. Almeida ${ }^{\text {b }}$ \\ a Departamento de Solos, Universidade Federal de Viçosa, Av. PH Rolfs s/n. Viçosa, 36570-000, Minas Gerais, Brazil \\ b Instituto Federal do Norte de Minas Gerais, Fazenda São Geraldo, s/n km. 06, 39480-000, Januária, Minas Gerais, Brazil
}

\section{A R T I C L E I N F O}

\section{Article history:}

Received 18 June 2012

Received in revised form 24 October 2012

Accepted 28 October 2012

Available online 5 December 2012

\section{Keywords:}

Soil microstructure

Phosphatic minerals

Phosphatization

WDS analysis

\begin{abstract}
A B S T R A C T
Micromorphological investigations of Antarctic soils are comparatively scarce, however, they could help understand the genesis of cryogenic soils under extreme polar conditions and different biotic factors. In most areas of Maritime Antarctica, the soil structure is apparently influenced by the local lithology, cryoturbation, guano deposition and reaction of guano solutions. The present study was carried out in Hope Bay, in the northern part of the Antarctic Peninsula, possibly one of the oldest sites of penguin occupation in the region. We describe and analyze the most important micro and sub-microscopic features of selected Ornithogenic Cryosols (Gelisols) from this part of Antarctic Peninsula, representing a transitional climatic zone between the wetter South Shetlands and the much drier Weddell Sea sector. Nine pedons representing the main ornithogenic soils found in ice-free areas of Hope Bay were selected for the micromorphological study. Undisturbed soil blocks were sampled at different depths, ranging between 0 and $30 \mathrm{~cm}$. The microstructure and sub-microstructure were further investigated using a JEOL 8200 and a Zeiss scanning electron microscopes, both coupled with an microprobe (SEM/WDS). These pedons have a very limited surface accumulation of organic matter formed by mosses and lichens, changing abruptly to a mineral phosphatic horizon of bleached colours, and usually hardcemented by ice. A small to medium-sized granular structure is generally observed, with ovoidal, subrounded forms, including several well-defined ornithogenic materials, such as P-rich organic remains, nodular phosphates forms and minute fragments of bone apatite. The chemical composition of ornithogenic materials and phosphatic coatings indicates the presence of discrete forms of taranakite, minyulite, leucophosphite, struvite and fluorapatite, typical of phosphatization process in these soils. Phosphatization and enhanced chemical alteration of the substrate and is one of the main soil-forming process in ornithogenic soils, resulting in P-rich ovoidal aggregates formation. P-rich solutions penetrate desiccation fractures and cleavage planes in large clasts and react preferably with plagioclases. P reacts with $\mathrm{Al}$ and $\mathrm{Fe}$ to form various amorphous and crystalline P phases. Present day permafrost cementation of deeper phosphate layers indicate that warmer/wetter conditions occurred in the past, during which $\mathrm{P}$ was leached downwards and reacted with the rock substrates, developing stable ovoidal aggregates, now incorporated in ice-cemented subsurface horizon.
\end{abstract}

(c) 2012 Elsevier B.V. All rights reserved.

\section{Introduction}

Micromorphological investigations of Antarctic soils are few (van Vliet-Lanöe et al., 2004). Pioneering works on the micromorphology of the Antarctic soils were made by Fitzpatrick (1956) and Kubiena (1970). Micromorphological analysis makes it possible to study the interrelationships between the various individual components, particles, and pores that make up sediments and soils. With regard to Antarctic soils, the micromorphological and microchemical studies can reveal important information regarding soil genesis and physicalchemical behavior (Schaefer et al., 2008).

At present, rock-inherited features, and secondary clays dominate cold regions and mountain soils, which also are subject to cryoturbation

\footnotetext{
* Corresponding author. Tel.: +55 3185977170.

E-mail address: torresthiago@yahoo.com.br (T.T.C. Pereira).
}

processes and reduced rates of soil development (van Vliet-Lanöe et al., 2004). The microstructure development in these environments is greatly influenced by the local lithology, and, in some cases, by the reaction of large amounts of guano. Different types of platy and granular fabrics (Schaefer et al., 2008; van Vliet-Lanöe, 1985) and eluviation-illuviation processes (Fox and Protz, 1981) are commonly reported in cryogenic soils from different cold environment.

A granular microstructure comprised of a granic/granoidic fabric is commonly observed in surface horizons and is replaced by a coalesced microstructure with depth (Schaefer et al., 2008; Smith et al., 1991; Tarnocai et al., 1993; White and Fox, 1997), and by an orbiculic fabric (van Vliet-Lanöe et al., 2004). Platy structure having a banded fabric occurs in Cryosols subjected to freezing and thawing processes (van VlietLanöe, 1985). Despite one the oldest human-visited region in Antarctica, no detailed pedological or micromorphological studies have been conducted in Cryosols from the Antarctic Peninsula. However, this area has a transitional climate between the dry, cold Polar Desert of 
the Weddell Sea islands and the warmer, wettest South Shetlands archipelago.

Soils from Maritime Antarctica are generally more developed than those from drier and colder climatic zones of Antarctica (Blume et al., 2004; Michel et al., 2006). In Hope Bay, we identified and characterized five soil units, highlighting: i) Turbic Cryosol (Ornithic)-(Ornithogenic Haploturbels); and ii) Turbic Cryosol (Lithic)-(Lithic Haploturbels). The occurrence of permafrost in the first $30 \mathrm{~cm}$ along almost the whole extension of Hope Bay has a strong regulating effect on soil leaching and development processes.

Although periglacial, physical weathering is undoubtedly a major soil-forming process in that part of Antarctica, chemical weathering also occurs, notably in ornithogenic soils (Michel et al., 2006; Simas et al., 2006). These soils are strongly affected by sea-land transfers of nutrients by birds, mostly penguins, through deposition and reaction of large amounts of guano during the austral summer. The fine fraction of these soils contains mainly phosphates of various chemical and mineral compositions (Tatur and Keck, 1990). In these soils, a particular and complex process of deep soil phosphatization occurs, which has been described in detail by Tatur and Barczuk (1985), Tatur (1989), Schaefer et al. (2004), and Simas et al. (2007).

The present study was carried out in Hope Bay, in the northern part of the Antarctic Peninsula, possibly one of the oldest sites of penguin occupation in the region. The most important micro and sub-microscopic features were described and analysed to assess their influences on genesis of ornithogenic soils from this part of Antarctic Peninsula, representing a transitional climatic zone between the humid South Shetlands archipelago and the drier Weddell Sea sector.

\section{Material and methods}

\subsection{Study area}

The study was conducted in Hope Bay, in the Northern end of the Antarctic Peninsula (Fig. 1). The area is bordered in the South by
Mount Flora (520 $\mathrm{m}$ asl) and in the East by the Buenos Aires glacier, whose snout reaches over $100 \mathrm{~m}$. SCAR (2002) defined the area of Mount Flora and surroundings as an Antarctic Specially Protected Area (ASPA 148). Excluding Mount Flora, the ice-free area between the sea and the glaciers covers a region of approximately $3 \mathrm{~km}^{2}$, with average elevations of $\leq 100 \mathrm{~m}$ (Birkenmajer, 1993a, Martín-Serrano et al., 2005).

According to Köppen's classification, the region is part of the EF (polar) climate. The average temperature of Hope Bay measured at Esperanza Station, between 1952 and 2010 was $-5.1{ }^{\circ} \mathrm{C}$, with annual precipitation of approximately $150 \mathrm{~mm}$, characterizing a polar semi-desert climate.

The geology of Hope Bay is composed of a metasedimentary (Trinity Peninsula Group-Hope Bay Formation-Permo-Carboniferous: marine siliciclastic turbidites and sandstones), sedimentary (Botany Bay GroupMount Flora Formation - Lower to Middle Jurassic: sandstones, conglomerates and bituminous schists) and volcanic rock sequences (Antarctic Peninsula Volcanic Group-Kenney Glacier Formation Lower Cretaceous: rhyolite-dacites, ignimbrites, conglomerates and cemented tuff) (Birkenmajer 1993b; del Valle et al. 2001; SCAR, 2002).

The geomorphology is related to both paraglacial and periglacial processes and landforms, reflecting the widespread late Quaternary retreat of glaciers (Martín-Serrano et al., 2005), with shorter intervals of minor glacial advances. Most geomorphic processes are related to the coastal environment, with persistent winds, summer melting, increasing periglacial erosion, and thermokarst features are common.

\subsection{Soil sampling}

Nine pedons representing the main ornithogenic soils found in ice-free areas of Hope Bay were selected for the micromorphological study, and all were classified as Cryosols/Gelisols, except for pedon 16 (Table 1). Detailed chemical, physical and mineralogical data regarding these soils are found in Pereira et al. (in press). The soil depths considered in the micromorphological analyses were $0-30 \mathrm{~cm}$ for all pedons.

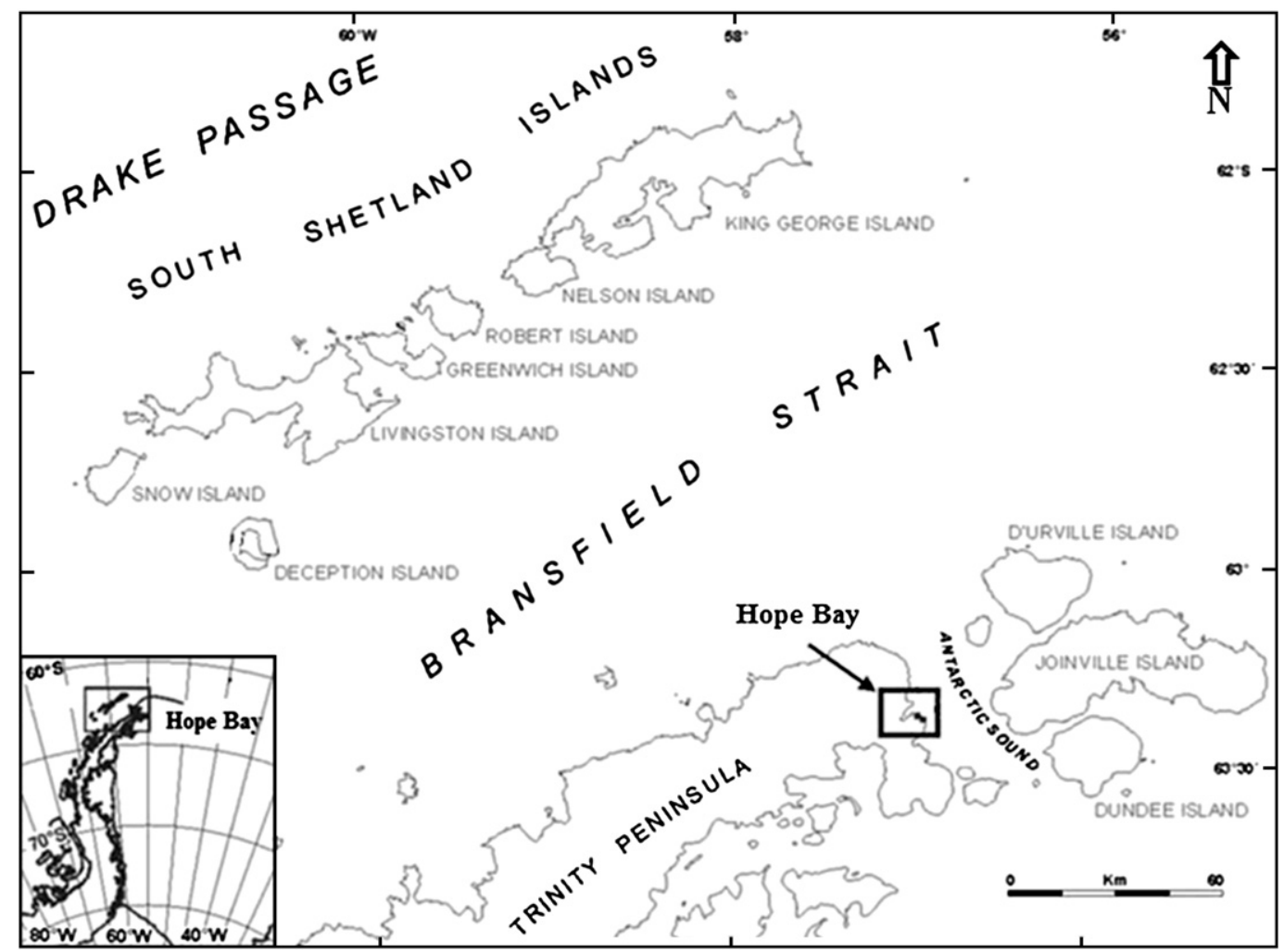

Fig. 1. Hope Bay, Antarctic Peninsula. Adapted from SCAR (2002). 


\subsection{Micromorphology}

Undisturbed soil blocks were sampled at different depths $(0-30 \mathrm{~cm}$ from the surface). All samples were dried at $50{ }^{\circ} \mathrm{C}$ and impregnated with a 1:1 crystic resin:styrene mix poured onto sample at vacuum. Impregnated samples were cut into slabs of $0.5 \mathrm{~cm}$ thickness using a diamond saw, and polished with corundum and diamond abrasives from 250 down to 600 mesh. After ultrasonic cleaning, the polished blocks were mounted onto glass slides followed by polishing and hand-finishing to produce $30 \mu \mathrm{m}$ thick, $10 \times 6 \mathrm{~cm}$ sized, thin-sections.
No cover slips were used, and fine ultrapolishing using diamond powder of decreasing size (60 to $1 \mu \mathrm{m}$ ) ensured that a final flat surface was produced. Thin-sections were examined under a Zeiss polarizing microscope (Optic Transmission Microscopy - OTM level) using an attached Pentax camera fitted with a Zeiss exposure meter. Pedological features of the soil horizons at OTM level were analysed using standard micromorphological techniques (Bullock et al., 1985). Selected areas described under the petrographic microscope (OTM) were submitted to SEM/WDS analysis in carbon-coated specimens, at high resolution.

Table 1

Main structural and microstructural characteristics of pedons studied.

\begin{tabular}{|c|c|c|c|c|c|}
\hline Pedon & Classification & Structure $^{\mathrm{a}}$ & Microstructure $^{\mathrm{b}}$ & $\mathrm{P}^{\mathrm{c}}$ & Main phosphate minerals (clay fraction) \\
\hline 1 & Ornithogenic Haploturbels & $\mathrm{w}, \mathrm{m}, \mathrm{gr}$ & $\begin{array}{l}\text { Type: granular (spheroidal peds) } \\
\text { Form: equidimensional and triaxial } \\
\text { Degree of rounding: rounded } \\
\text { Surface roughness: smooth } \\
\text { Related distribution pattern }{ }^{\mathrm{d}} \text { : enaulic/gefuric } \\
\text { Degree of aggregate development: moderate/strong } \\
\text { Pores: complex }\end{array}$ & 6010.6 & $\begin{array}{l}\text { Taranakite, minyulite, leucophosphite, } \\
\text { fluorapatite }\end{array}$ \\
\hline 3 & Ornithogenic Haploturbels & st, m, gr & $\begin{array}{l}\text { Type: granular (spheroidal peds) } \\
\text { Form: equidimensional and triaxial } \\
\text { Degree of rounding: subrounded to rounded } \\
\text { Surface roughness: smooth } \\
\text { Related distribution pattern }{ }^{\mathrm{d}} \text { : gefuric/chitonic } \\
\text { Degree of aggregate development: strong } \\
\text { Pores: complex }\end{array}$ & 7149.6 & Taranakite \\
\hline 4 & Ornithogenic Haploturbels & $\mathrm{md} / \mathrm{st}, \mathrm{m}, \mathrm{gr}$ & $\begin{array}{l}\text { Type: granular (spheroidal peds) } \\
\text { Form: equidimensional } \\
\text { Degree of rounding: subrounded to rounded } \\
\text { Surface roughness: wavy/smooth } \\
\text { Related distribution pattern }{ }^{\mathrm{d}} \text { : chitonic (part porphyric) } \\
\text { Degree of aggregate development: strong } \\
\text { Pores: complex }\end{array}$ & 7149.6 & Taranakite \\
\hline 7 & Ornithogenic Haploturbels & $\mathrm{md} / \mathrm{st}, \mathrm{m}, \mathrm{gr}$ & $\begin{array}{l}\text { Type: granular (spheroidal peds) } \\
\text { Form: equidimensional } \\
\text { Degree of rounding: subrounded } \\
\text { Surface roughness: smooth } \\
\text { Related distribution pattern }{ }^{\mathrm{d}} \text { : gefuric } \\
\text { Degree of aggregate development: weak/moderate } \\
\text { Pores: complex }\end{array}$ & 7237.3 & $\begin{array}{l}\text { Taranakite, leucophosphite, } \\
\text { struvite, fluorapatite }\end{array}$ \\
\hline 14 & Ornithogenic (Anthropic) Haploturbels & $\mathrm{w}, \mathrm{f}, \mathrm{gr}, / \mathrm{sg}$ & $\begin{array}{l}\text { Type: granular (spheroidal peds) } \\
\text { Form: equidimensional and triaxial } \\
\text { Degree of rounding: subrounded } \\
\text { Surface roughness: smooth } \\
\text { Related distribution pattern }{ }^{\mathrm{d}} \text { : gefuric (part porphyric) } \\
\text { Degree of aggregate development: strong } \\
\text { Pores: complex }\end{array}$ & 996.3 & $\begin{array}{l}\text { Taranakite, minyulite, leucophosphite, } \\
\text { struvite, fluorapatite }\end{array}$ \\
\hline 15 & Ornithogenic (Anthropic) Haploturbels & $\mathrm{w}, \mathrm{f}, \mathrm{gr} / \mathrm{sg}$ & $\begin{array}{l}\text { Type: granular (spheroidal peds) } \\
\text { Form: equidimensional and triaxial } \\
\text { Degree of rounding: subrounded } \\
\text { Surface roughness: smooth } \\
\text { Related distribution pattern }{ }^{\mathrm{d}} \text { : gefuric (part porphyric) } \\
\text { Degree of aggregate development: moderate } \\
\text { Pores: complex }\end{array}$ & 586.4 & $\begin{array}{l}\text { Taranakite, minyulite, leucophosphite, } \\
\text { struvite, fluorapatite }\end{array}$ \\
\hline 16 & Ornithogenic Gelorthents & sg & $\begin{array}{l}\text { Type: massive (apedal) or vughy/weakly developed } \\
\text { subangular blocky peds } \\
\text { Form: equidimensional and triaxial } \\
\text { Degree of rounding: subrounded } \\
\text { Surface roughness: smooth } \\
\text { Related distribution pattern }{ }^{\mathrm{d}} \text { : porphyric } \\
\text { Degree of aggregate development: weak } \\
\text { Pores: complex }\end{array}$ & 5765.3 & Taranakite, minyulite, fluorapatite \\
\hline 17 & Ornithogenic Haploturbels & - & $\begin{array}{l}\text { Type: granular (spheroidal peds) } \\
\text { Form: equidimensional } \\
\text { Degree of rounding: subrounded } \\
\text { Surface roughness: wavy } \\
\text { Related distribution pattern }{ }^{\mathrm{d}} \text { : chitonic } \\
\text { Degree of aggregate development: strong } \\
\text { Pores: complex }\end{array}$ & 5527.3 & $\begin{array}{l}\text { Taranakite, leucophosphite, minyulite, } \\
\text { struvite, fluorapatite }\end{array}$ \\
\hline
\end{tabular}

\footnotetext{
a Development: $\mathrm{w}=$ weak, $\mathrm{md}=$ moderate, $\mathrm{st}=$ strong. Size: $\mathrm{f}=$ fine, $\mathrm{m}=$ medium. Type: $\mathrm{gr}=$ granular, $\mathrm{sg}=$ single grain

b According to Brewer (1964), Stoops and Jongerius (1977), and Bullock et al. (1985).

c P Mehlich-1 mean.

d Related distribution pattern follows Stoops and Jongerius (1977).
} 

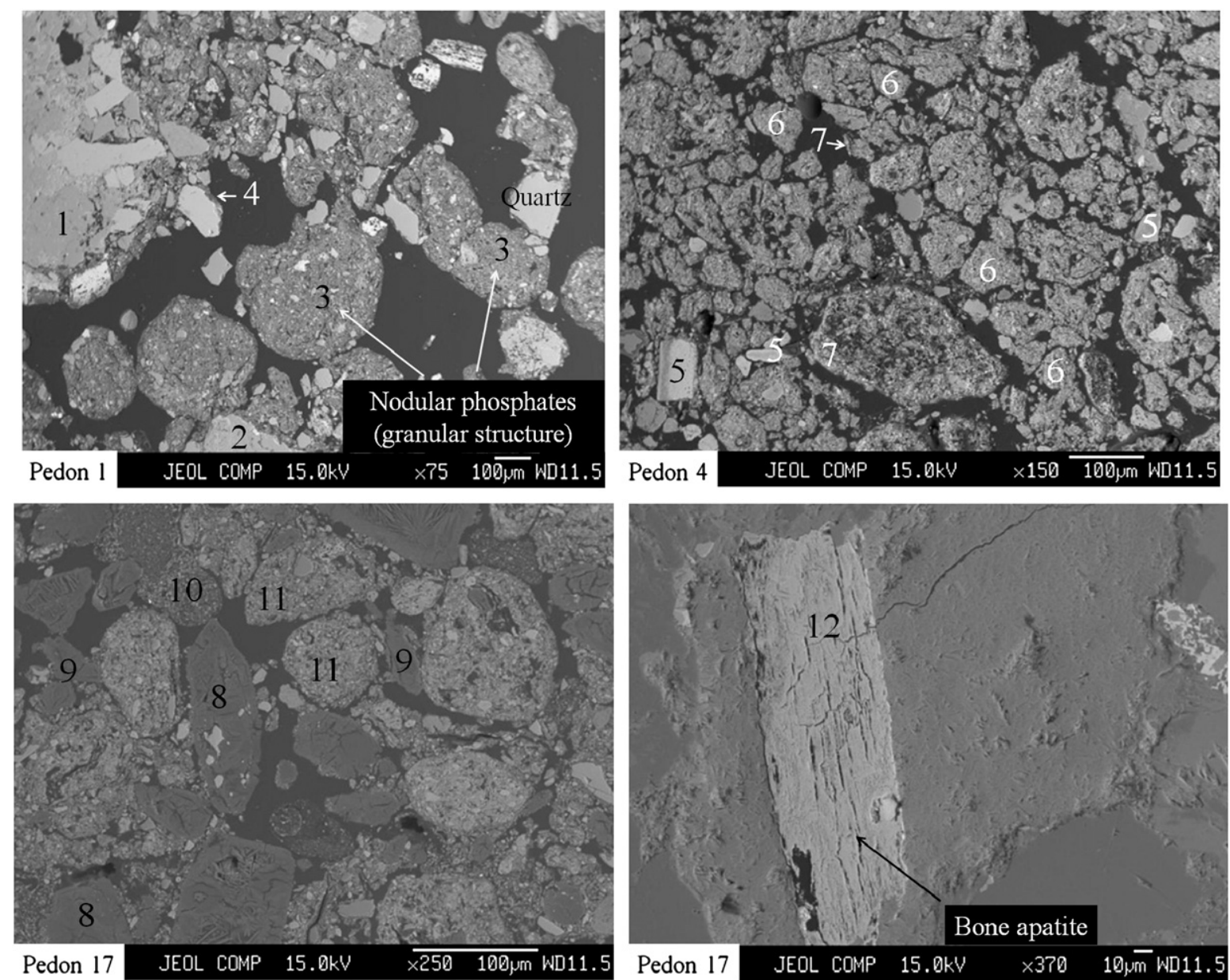

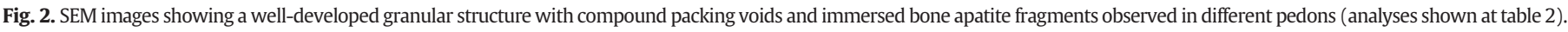

\subsection{Sub-microscopy and electron microscopy analysis: SEM/WDS}

In all soil thin-sections, the microstructure and sub-microstructure were further investigated using a JEOL 8200 and a Zeiss scanning electron microscopes, both coupled with an Oxford energy dispersive $\mathrm{X}$-ray detector (SEM/WDS), following the recommendations of Bisdom and Ducloux (1983). Microchemical analyses were acquired at 17 to $18 \mathrm{~mm}$ working distance and $15 \mathrm{kV}$ accelerating voltage.

\section{Results and discussion}

All pedons studied represent typical ornithogenic soils from the Antarctic Peninsula. They have a surface accumulation of organic matter derived from guano deposition, under discontinuous mosses and lichens cover, changing abruptly to a mineral phosphatic horizon of bleached colours, and usually cemented. Some characteristics of soils studied are illustrated in Table 1.

Table 2

WDS analysis of selected micropedological features observed in pedons studied.

\begin{tabular}{|c|c|c|c|c|c|c|c|c|c|c|c|}
\hline \multirow[t]{2}{*}{ Pedofeature } & \multirow[t]{2}{*}{$n$} & $\mathrm{CaO}$ & $\mathrm{MgO}$ & $\mathrm{Na}_{2} \mathrm{O}$ & $\mathrm{K}_{2} \mathrm{O}$ & $\mathrm{SiO}_{2}$ & $\mathrm{Al}_{2} \mathrm{O}_{3}$ & $\mathrm{P}_{2} \mathrm{O}_{5}$ & $\mathrm{Fe}_{2} \mathrm{O}_{3}$ & $\mathrm{~F}$ & Total \\
\hline & & \multicolumn{10}{|l|}{$\%$} \\
\hline \multicolumn{12}{|c|}{ Pedon 1 - Ornithogenic Haploturbels } \\
\hline $1^{\mathrm{a}} \mathrm{Na}$-plagioclase & 4 & $0.5 \pm 0.1$ & nd & $11.1 \pm 0.9$ & $0.4 \pm 0.5$ & $69.8 \pm 0.8$ & $19.9 \pm 0.6$ & nd & nd & nd & $101.8 \pm 1.6$ \\
\hline $2^{\mathrm{a}} \mathrm{K}$-plagioclase & 2 & nd & nd & $0.9 \pm 0.7$ & $15.1 \pm 1.2$ & $66.9 \pm 0.5$ & $17.7 \pm 0.2$ & nd & $0.1 \pm 0.0$ & nd & $101.8 \pm 0.2$ \\
\hline $3^{\mathrm{a}}$ Fluorapatite & 13 & $45.4 \pm 8.9$ & $0.6 \pm 0.3$ & $0.8 \pm 0.7$ & nd & nd & nd & $18.3 \pm 2.9$ & $1.9 \pm 0.9$ & $1.4 \pm 0.3$ & $68.5 \pm 10.4$ \\
\hline $4^{\mathrm{a}}$ Leucophosphite & 4 & $1.6 \pm 1.0$ & $0.2 \pm 0.1$ & $0.1 \pm 0.1$ & $0.9 \pm 0.2$ & $5.2 \pm 2.4$ & $5.3 \pm 0.5$ & $13.0 \pm 1.3$ & $14.1 \pm 1.7$ & $0.3 \pm 0.2$ & $40.8 \pm 2.1$ \\
\hline \multicolumn{12}{|c|}{ Pedon 4 - Ornithogenic Haploturbels } \\
\hline $5^{\mathrm{a}} \mathrm{Na}$-plagioclase & 5 & $0.8 \pm 0.7$ & $0.1 \pm 0.1$ & $10.1 \pm 2.0$ & $1.2 \pm 1.3$ & $66.0 \pm 4.5$ & $21.2 \pm 1.5$ & nd & $0.1 \pm 0.0$ & nd & $99.2 \pm 3.9$ \\
\hline $6^{\text {a }}$ Fluorapatite & 17 & $41.4 \pm 5.5$ & $0.4 \pm 0.1$ & $0.6 \pm 0.2$ & $0.1 \pm 0.0$ & $0.9 \pm 0.8$ & $1.0 \pm 0.3$ & $15.3 \pm 2.4$ & $0.4 \pm 0.1$ & $1.1 \pm 0.2$ & $61.0 \pm 7.2$ \\
\hline $7^{\text {a }}$ Leucophosphite & 1 & 2.7 & 0.4 & 0.4 & 1.1 & 0.4 & 1.5 & 13.4 & 19.6 & nd & 39.5 \\
\hline \multicolumn{12}{|c|}{ Pedon 17 - Ornithogenic Haploturbels } \\
\hline $8^{\mathrm{a}} \mathrm{K}$-plagioclase & 4 & $0.0 \pm 0.0$ & nd & $0.5 \pm 0.2$ & $15.7 \pm 0.2$ & $67.3 \pm 0.7$ & $18.4 \pm 0.2$ & nd & $0.0 \pm 0.0$ & nd & $102.0 \pm 0.7$ \\
\hline $9^{\mathrm{a}} \mathrm{Na}$-plagioclase & 2 & $0.7 \pm 0.2$ & $0.2 \pm 0.2$ & $9.3 \pm 0.1$ & $1.6 \pm 0.4$ & $67.2 \pm 0.1$ & $21.8 \pm 0.2$ & nd & $0.3 \pm 0.1$ & nd & $101.1 \pm 0.1$ \\
\hline $10^{\mathrm{a}}$ Struvite & 7 & $0.8 \pm 1.3$ & $21.4 \pm 2.0$ & $0.1 \pm 0.1$ & $0.0 \pm 0.0$ & $0.7 \pm 1.6$ & $0.2 \pm 0.1$ & $17.4 \pm 1.7$ & $0.1 \pm 0.0$ & $0.2 \pm 0.1$ & $40.9 \pm 0.9$ \\
\hline $11^{\mathrm{a}}$ Taranakite & 2 & $0.3 \pm 0.1$ & $0.3 \pm 0.1$ & $0.0 \pm 0.0$ & $6.5 \pm 0.0$ & $0.4 \pm 0.1$ & $28.0 \pm 1.1$ & $18.6 \pm 0.6$ & $0.7 \pm 0.1$ & $0.9 \pm 0.3$ & $55.8 \pm 1.9$ \\
\hline $12^{\mathrm{a}}$ Bone apatite & 10 & $43.9 \pm 5.3$ & $1.5 \pm 0.5$ & $0.6 \pm 0.3$ & $0.3 \pm 0.2$ & $2.7 \pm 2.0$ & $2.1 \pm 1.4$ & $16.6 \pm 1.3$ & $0.8 \pm 0.4$ & $1.1 \pm 0.3$ & $69.2 \pm 5.6$ \\
\hline
\end{tabular}

$n$ : number of analysis; nd: not determined.

a Illustrated in Fig. 2. 

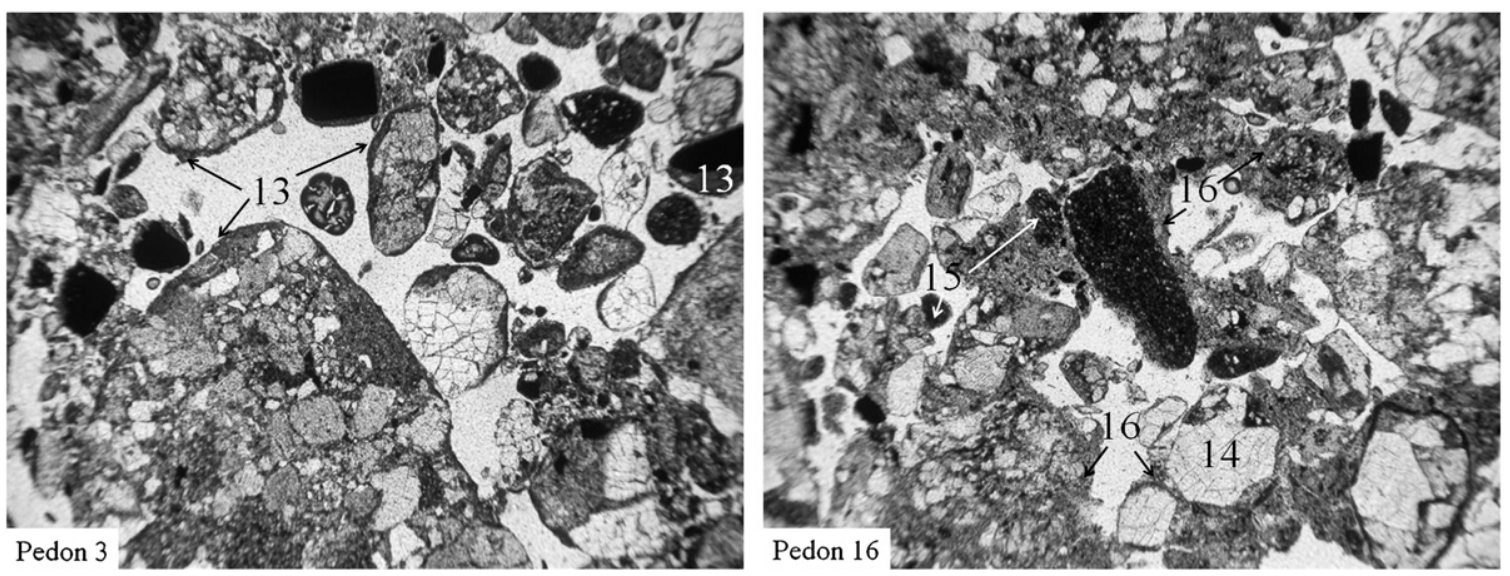

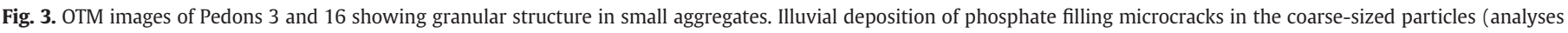
shown at table 3 )

Table 3

WDS analysis of micropedological features observed in pedons studied.

\begin{tabular}{|c|c|c|c|c|c|c|c|c|c|c|c|}
\hline \multirow[t]{2}{*}{ Pedofeature } & \multirow[t]{2}{*}{$n$} & $\mathrm{CaO}$ & $\mathrm{MgO}$ & $\mathrm{Na}_{2} \mathrm{O}$ & $\mathrm{K}_{2} \mathrm{O}$ & $\mathrm{SiO}_{2}$ & $\mathrm{Al}_{2} \mathrm{O}_{3}$ & $\mathrm{P}_{2} \mathrm{O}_{5}$ & $\mathrm{Fe}_{2} \mathrm{O}_{3}$ & $\mathrm{~F}$ & Total \\
\hline & & \multicolumn{10}{|l|}{$\%$} \\
\hline \multicolumn{12}{|c|}{ Pedon 3 - Ornithogenic Haploturbels } \\
\hline $13^{\mathrm{a}}$ Illuvial phosphate & 7 & $26.2 \pm 5.8$ & $1.7 \pm 0.3$ & $0.5 \pm 0.2$ & $0.4 \pm 0.2$ & $4.7 \pm 2.1$ & $2.6 \pm 1.4$ & $12.0 \pm 1.2$ & $1.1 \pm 0.8$ & $0.8 \pm 0.3$ & $50.2 \pm 8.4$ \\
\hline \multicolumn{12}{|c|}{ Pedon 16 - Ornithogenic Gelorthents } \\
\hline $14^{\mathrm{a}} \mathrm{Na}-\mathrm{Plagioclase}$ & 1 & 0.2 & 0.1 & 5.0 & 0.2 & 86.6 & 8.0 & nd & 1.8 & nd & 101.9 \\
\hline $15^{\mathrm{a}} \mathrm{Fe}(\mathrm{OH})_{3}$ form with $\mathrm{P}$ & 11 & $0.8 \pm 0.1$ & $0.4 \pm 0.0$ & $0.4 \pm 0.1$ & nd & $0.8 \pm 0.4$ & $1.3 \pm 0.6$ & $4.3 \pm 0.4$ & $88.3 \pm 1.8$ & nd & $96.6 \pm 0.9$ \\
\hline $16^{\mathrm{a}}$ Illuvial phosphate & 25 & $41.4 \pm 3.8$ & $0.6 \pm 0.1$ & $0.9 \pm 0.1$ & $0.3 \pm 0.2$ & $1.4 \pm 1.0$ & $4.0 \pm 0.8$ & $18.0 \pm 1.8$ & $2.4 \pm 1.3$ & $1.4 \pm 0.3$ & $70.7 \pm 4.2$ \\
\hline
\end{tabular}

$n$ : number of analysis; nd: not determined.

a Illustrated in Fig. 3.

In general, the soils have a weak to moderate structural development, varying primarily between subangular blocky and granular. Soil microfabrics have a moderate or strong structural development. At this scale, a small to medium-sized granular structure is generally observed, with rounded to subrounded forms, including several well-defined ornithogenic pedofeatures, such as P-rich organic remains, nodular phosphates forms and minute fragments of bone apatite (Fig. 2), with chemical composition presented in Table 2. The microstructure is typically orbiculic, ovoidal-shaped, consistent with that described by van Vliet-Lanöe et al. (2004) for cryogenic fabrics of Cryosols from Canada. These materials are usually surrounded by cumulative concentric illuvial deposition of phosphates. van Vliet-Lanöe (1985) and Schaefer et al. (2004) noted that phosphatic coatings on clastic grains, formed as a result of pressured ultra-desiccation of the colloids during the freezing process, which make the granular units resistant to cryoturbation effects, mass wasting stresses, and collapse on thawing.

Fragments of plagioclases and quartz in all soils occur in varying size ranges ( $<$ or $>2 \mathrm{~mm}$ ), indicating the effectiveness of physical weathering and particle size reduction through freeze-and-thawing processes.

The highly diverse size of clasts and grains indicate that soils of this region are formed from extensive mechanical reworking and disintegration. This is expected in this part of Antarctica, as a result of solifluction, cryoturbation and other periglacial process normally occurring in Turbels (Schaefer et al., 2008).

The sub-angular characteristic of sand-sized and coarser particles indicate short-distance transport and physical disruption following thermal microcracking, some with illuvial deposition of phosphates (Fig. 3). The chemical composition of selected pedofeatures is presented in Table 3.

Increasing roundness of lithorelicts with decreasing particle size reflects the effects of differential frost heaving and intense cryoturbation during freeze-and-thawing cycles, creating ovoidal, granular-shaped, stable peds mostly polygenetic.

At the OTM level, illuvial phosphatic clay occur as bright yellow infillings along cleavage lines or broken, cryoturbic fragments of rocks and aggregates, with good orientation (Fig. 4).

The P-rich solution penetrates in cracks and cleavage planes and reacts preferentially with plagioclases forming a framework of phosphatic rims around these materials. According to Schaefer et al. (2008), this reaction with P-rich solutions leads to the progressive displacement of silica from rock minerals, and consequently, enhanced chemical weathering.

Based on microchemistry mapping, the fine material is dominated by phosphatic aggregates (Figs. 5 to 9). In all pedons, phosphatization

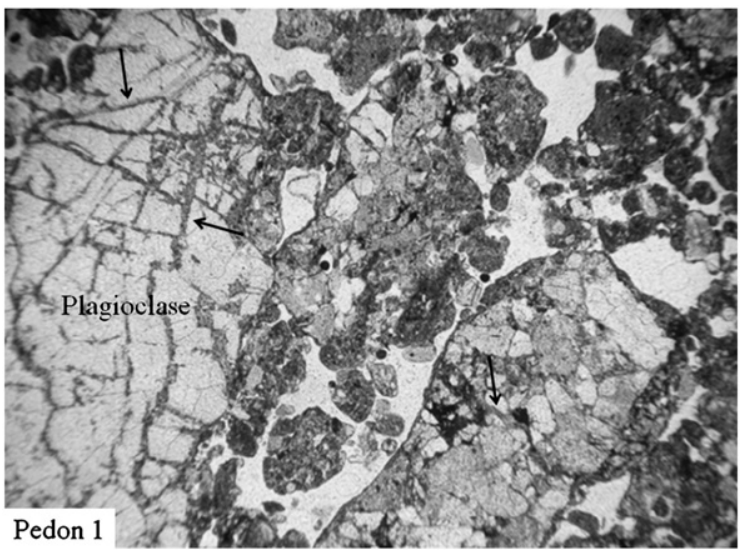

Fig. 4. OTM images showing illuvial phosphatic features in cryoturbic fragments indicated by black arrows. The WDS mean results were $16.8 \% \mathrm{P}_{2} \mathrm{O}_{5}$ for these illuvial phosphates. 


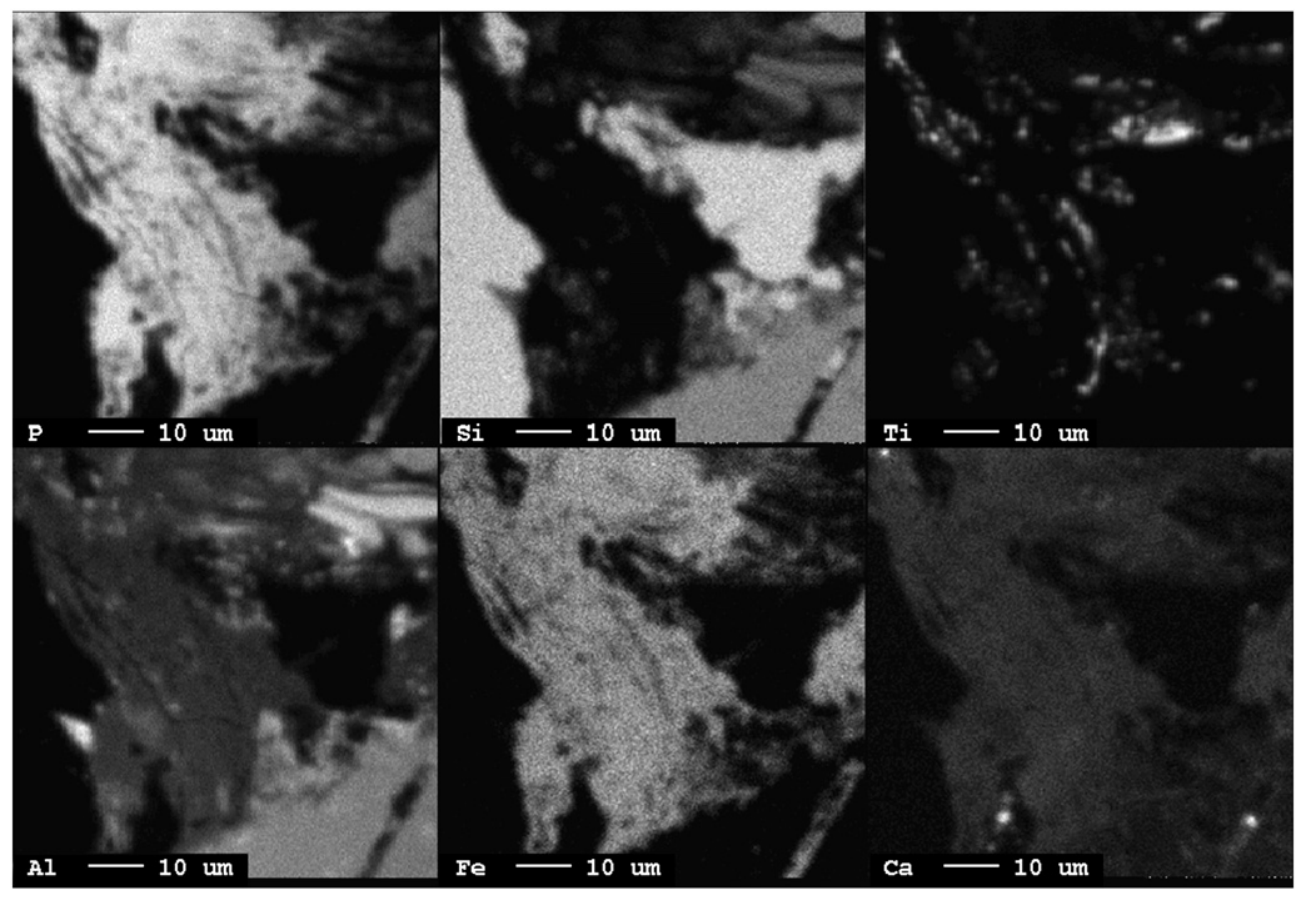

Fig. 5. Qualitative WDS analysis showing phosphatic soil matrix, indicating leucophosphite, fluorapatite, taranakite and minyulite phases (pedon 1).

process occurs throughout, with a combination of $\mathrm{P}-\mathrm{Al}-\mathrm{Fe}$ phases mainly, but also P-Ca or P-Mg.

The chemical composition of the secondary phosphate reflects the nature of the lithofragment that is phosphatized (Table 4). The clasts and grains are composed almost exclusively of plagioclases and quartz, so that $\mathrm{Al}$ and $\mathrm{Si}$ released from acidolysis. The chemical alteration of the grain leads to $\mathrm{P}$ reacting with $\mathrm{Al}$ and $\mathrm{Fe}$ to form various amorphous and crystalline $\mathrm{P}$ phases. According to Blume et al. (2004) and Simas et al. (2006), non-crystalline phases are important soil components and reach $>75 \%$ of the clay fraction for some ornithogenic soils. Following reaction, the newly formed aluminium-iron phosphates are concentrated in infillings or as illuvial coating, creating the typical phosphate rich ovoidal aggregates by ultra-desiccation.

Transects analysis were made from the fine soil matrix to the primary Al-silicates that compose the clasts (Figs. 10 and 11). Si and Al peaks increasing intensity indicates the presence of Al-silicates, which may be clays or primary minerals. P reaction with $\mathrm{Ca}, \mathrm{Fe}, \mathrm{Mg}$ and $\mathrm{K}$ occurs on the edges or within primary minerals, suggesting that phosphates rich liquid leachates have throughout soaked the clasts in a typical phosphatization process, before were eventually dryed-up by freezing and desiccation.

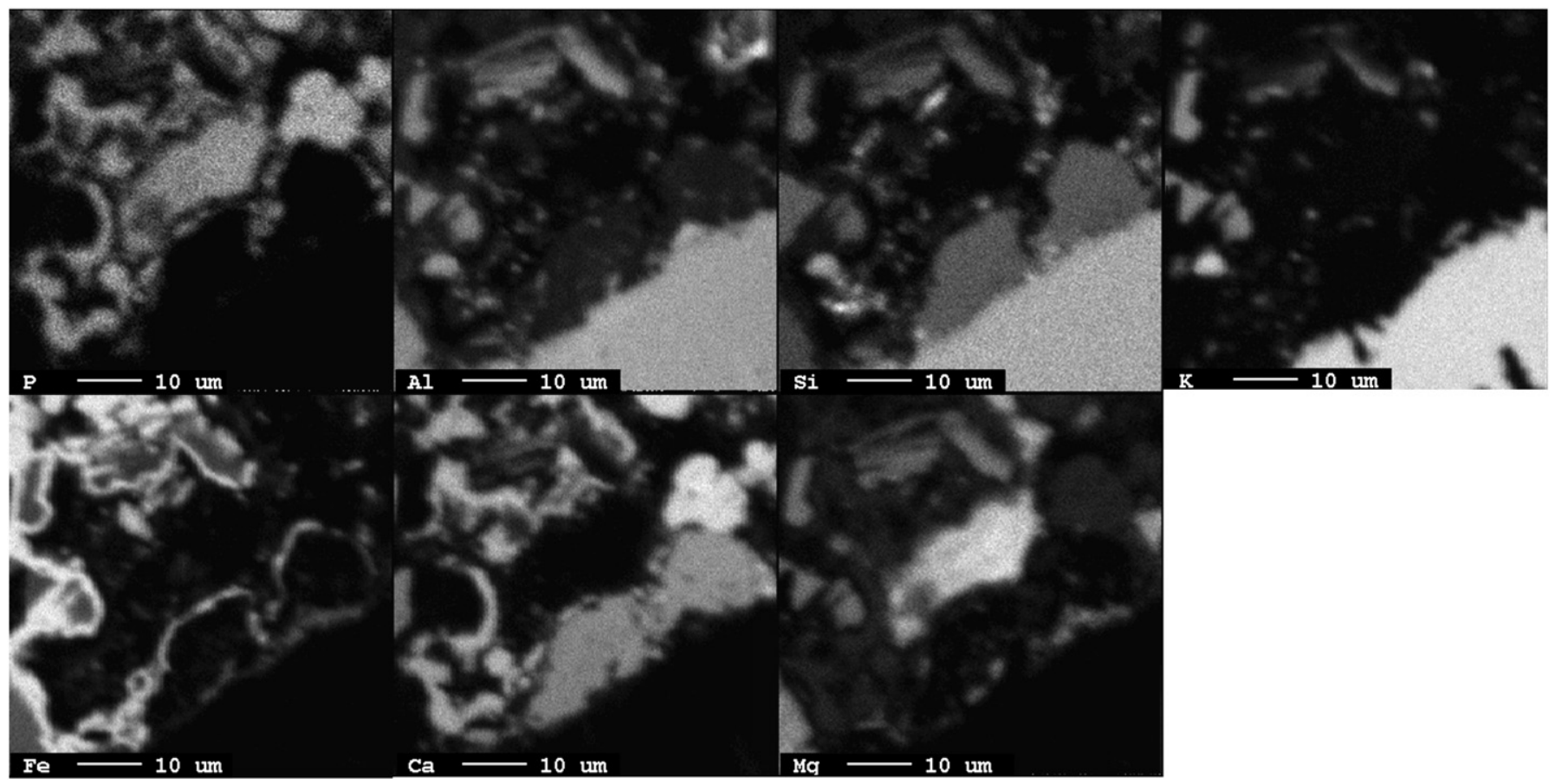

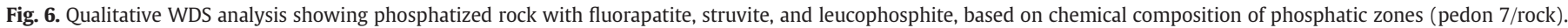




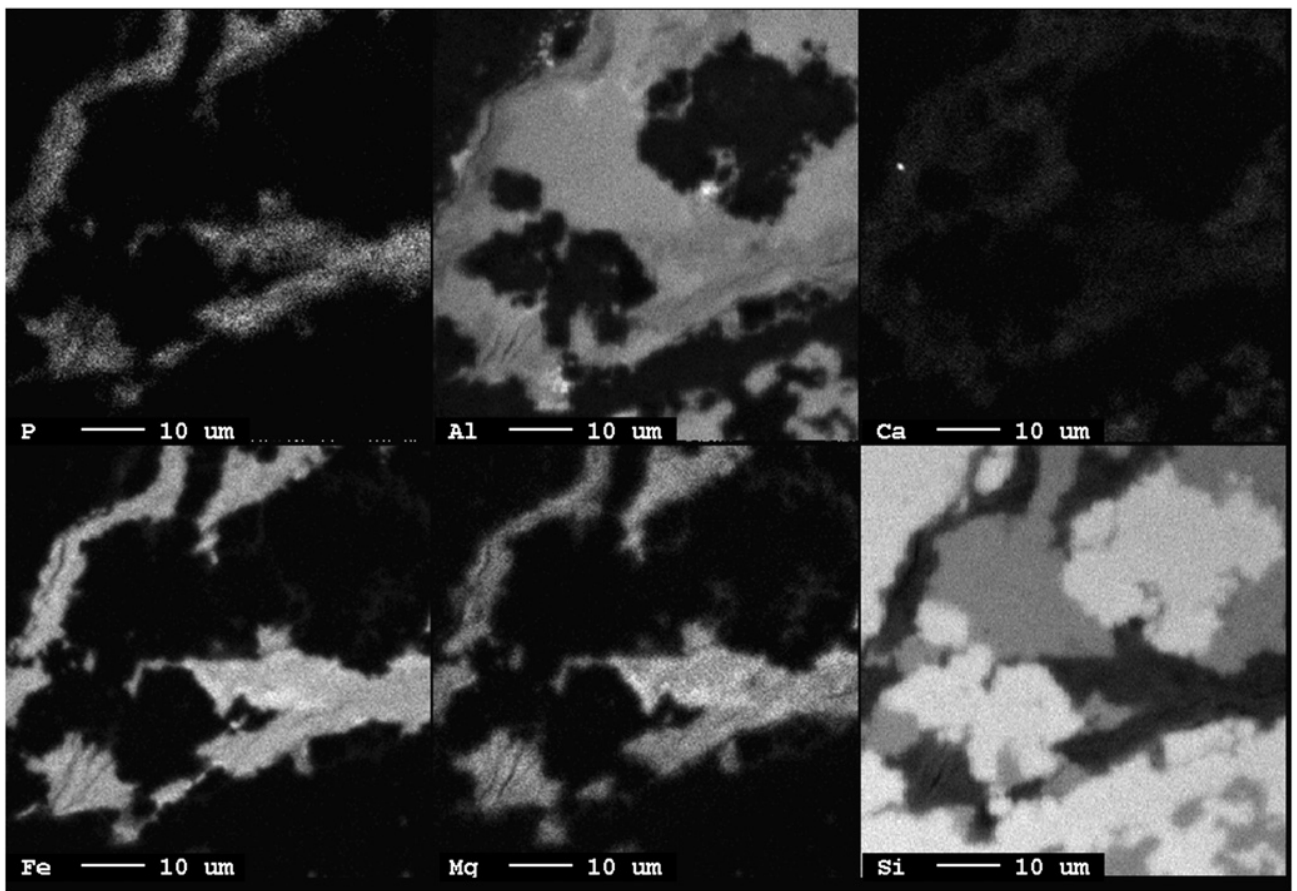

Fig. 7. Qualitative WDS analysis showing microfabric with coatings of taranakite, leucophosphite and struvite (pedon 14).

The chemical composition of some features and X-ray in the clay fraction indicates the presence of discrete forms of taranakite $\left((\mathrm{K}, \mathrm{NH} 4)_{3} \mathrm{Al}_{5} \mathrm{H}_{6}\left(\mathrm{PO}_{4}\right)_{8 \mathrm{x}} 18 \mathrm{H}_{2} \mathrm{O}\right)$, minyulite $\left(\mathrm{KAl}_{2}\left(\mathrm{PO}_{4}\right)_{2}(\mathrm{OH}, \mathrm{F}) .4\left(\mathrm{H}_{2} \mathrm{O}\right)\right)$, leucophosphite $\left(\left(\mathrm{NH}_{4}, \mathrm{~K}\right)_{2}(\mathrm{Fe}, \mathrm{Al})_{4}\left(\mathrm{PO}_{4}\right)_{4}(\mathrm{OH}, \mathrm{F})_{2} \times 2 \mathrm{H}_{2} \mathrm{O}\right)$, struvite $\left(\left(\mathrm{NH}_{4}\right) \mathrm{MgPO}_{4} \cdot 6\left(\mathrm{H}_{2} \mathrm{O}\right)\right)$, and fluorapatite $\left(\mathrm{Ca}_{5}\left(\mathrm{PO}_{4}\right) \mathrm{F}\right)$ (Fig. 12), all typical of phosphatization process in ornithogenic soils (Tatur, 1989). However, P and K levels are lower than expected. Concerning the K concentration, Schaefer et al. (2008) indicate that these are degraded phases of these minerals that have lost part of $\mathrm{K}$, and the lower $\mathrm{K}$ amounts may indicate that these minerals contain high proportions of $\mathrm{NH}_{4}$ in their structures, since $\mathrm{N}$ was not analyzed by WDS.

Is notorious in many pedons the affinity between $\mathrm{P}$, Fe and $\mathrm{Al}$ (Fig. 10), indicating P-solutions preferably reacts with these elements on the primary mineral surfaces. These may represent very reactive amorphous Fe-Al phases with high P adsorption capacity (Schaefer et al., 2008).

Higher levels of $\mathrm{Fe}_{2} \mathrm{O}_{3}$ were detected, and pedofeatures were sometimes identified as $\mathrm{Fe}(\mathrm{OH})_{3}$ hydroxides. In Ornithogenic (Anthropic) Haploturbels, the contents of $\mathrm{Fe}_{2} \mathrm{O}_{3}$ associated with oxidized debris,

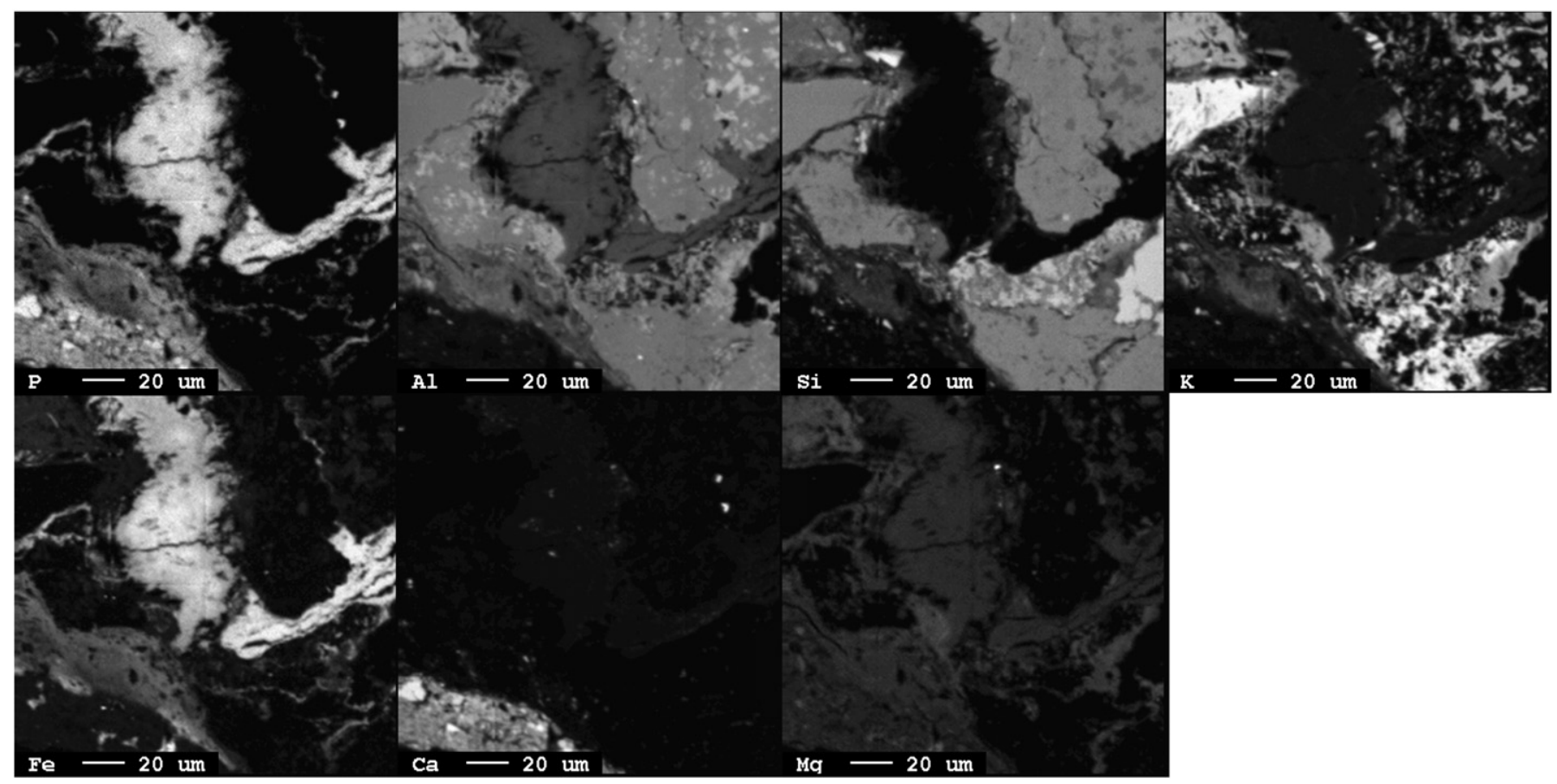

Fig. 8. Qualitative WDS analysis showing clasts filled with leucophosphite (mainly), and fluorapatite, taranakite, minyulite, struvite, based on chemical composition (pedon 17). 


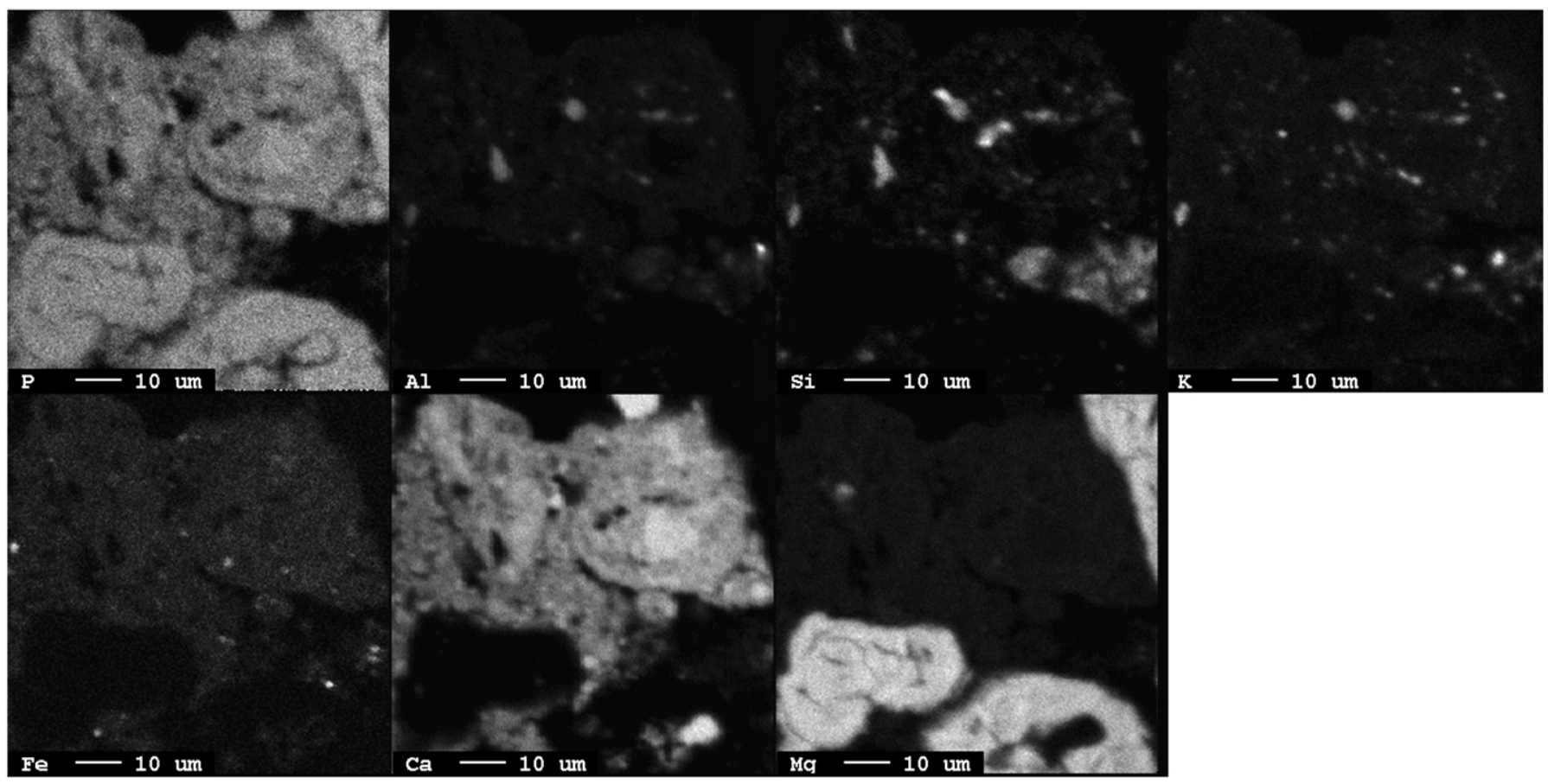

Fig. 9. Qualitative WDS analysis showing subrounded forms of struvite and fluorapatite in pedon 17.

have contributed to the different phosphate forms on the mineral substrate of these sites. In pedon 15 (Table 4), a sequence of WDS analysis in Fe-oxides departing from the soil matrix to the inside of the primary mineral suggests phosphate chemical attack.

Kaolinite, detected by X-ray in the clay fraction treatments (Fig. 13), was not chemically identified by WDS analysis, although some plasma compositions suggest their probable occurrence.
In pedon 14, the detection of illite, precursor of kaolinite, may help to elucidate its existence. Tarnocai and Valentine (1989) showed the presence of kaolinite microaggregates in Cryosols of Canada corresponding to materials formed during warm periods, related to the recently deglaciated areas with evidence of higher chemical weathering. The formation of these minerals in the clay fraction of soils of Hope Bay may be similar.

Table 4

WDS analysis of micropedological features observed in pedons studied.

\begin{tabular}{|c|c|c|c|c|c|c|c|c|c|c|c|}
\hline \multirow[t]{2}{*}{ Pedofeature } & \multirow[t]{2}{*}{$n$} & $\mathrm{CaO}$ & $\mathrm{MgO}$ & $\mathrm{Na}_{2} \mathrm{O}$ & $\mathrm{K}_{2} \mathrm{O}$ & $\mathrm{SiO}_{2}$ & $\mathrm{Al}_{2} \mathrm{O}_{3}$ & $\mathrm{P}_{2} \mathrm{O}_{5}$ & $\mathrm{Fe}_{2} \mathrm{O}_{3}$ & $\mathrm{~F}$ & Total \\
\hline & & \multicolumn{10}{|l|}{$\%$} \\
\hline \multicolumn{12}{|c|}{ Pedon 7 - Ornithogenic Haploturbels } \\
\hline Fluorapatite & 1 & 58.5 & nd & 0.1 & 0.0 & 0.6 & 0.6 & 21.7 & 0.1 & 1.5 & 83.1 \\
\hline Al-silicate (P-Fe-K) & 1 & 3.1 & 5.4 & 1.3 & 7.4 & 34.1 & 12.1 & 6.3 & 9.1 & 0.1 & 78.8 \\
\hline \multicolumn{12}{|l|}{ Pedon $7 /$ rock fragment } \\
\hline K-plagioclase & 5 & $0.1 \pm 0.1$ & $0.2 \pm 0.2$ & $0.5 \pm 0.6$ & $15.5 \pm 0.7$ & $66.9 \pm 0.5$ & $18.5 \pm 0.2$ & nd & $0.6 \pm 0.3$ & nd & $102.5 \pm 0.2$ \\
\hline $\mathrm{Ca}-\mathrm{Na}$-plagioclase & 2 & $5.2 \pm 1.2$ & $0.0 \pm 0.0$ & $6.9 \pm 2.1$ & $0.2 \pm 0.1$ & $68.4 \pm 6.1$ & $20.4 \pm 4.9$ & nd & $1.0 \pm 1.2$ & nd & $102.0 \pm 1.4$ \\
\hline Na-plagioclase & 1 & 0.5 & nd & 10.9 & 0.1 & 70.0 & 20.0 & nd & 0.1 & nd & 101.6 \\
\hline Al-silicate (Fe-Mg) & 3 & $0.2 \pm 0.0$ & $17.2 \pm 0.6$ & $0.0 \pm 0.0$ & $0.9 \pm 0.7$ & $29.9 \pm 1.3$ & $19.2 \pm 1.9$ & nd & $16.4 \pm 1.4$ & nd & $84.8 \pm 1.2$ \\
\hline $\mathrm{Fe}(\mathrm{OH})_{3}$ forms with $\mathrm{P}$ & 10 & $1.6 \pm 0.3$ & $1.3 \pm 0.4$ & $0.4 \pm 0.1$ & $0.7 \pm 0.5$ & $2.1 \pm 0.9$ & $5.1 \pm 0.7$ & $3.1 \pm 0.3$ & $61.0 \pm 2.4$ & $0.1 \pm 0.1$ & $75.5 \pm 3.0$ \\
\hline Fluorapatite & 2 & $53.1 \pm 4.8$ & $1.8 \pm 1.9$ & $0.7 \pm 0.7$ & 0.1 & $0.3 \pm 0.2$ & $0.2 \pm 1.2$ & $21.4 \pm 0.2$ & $1.1 \pm 0.9$ & $0.9 \pm 0.0$ & $80.0 \pm 2.5$ \\
\hline \multicolumn{12}{|c|}{ Pedon 14 - Ornithogenic (Anthropic) Haploturbels } \\
\hline Na-plagioclase $(\mathrm{P})$ & 1 & 0.4 & 0.4 & 9.1 & 0.7 & 67.0 & 15.1 & 0.8 & 1.0 & 0.0 & 94.5 \\
\hline K-plagioclase & 1 & nd & nd & 0.3 & 15.9 & 66.8 & 18.1 & nd & 0.0 & nd & 101.2 \\
\hline Illite & 3 & $0.2 \pm 0.0$ & $2.8 \pm 0.3$ & $0.4 \pm 0.6$ & $8.6 \pm 0.8$ & $51.4 \pm 3.5$ & $26.8 \pm 5.0$ & nd & $1.9 \pm 0.2$ & $0.0 \pm 0.0$ & $92.2 \pm 3.2$ \\
\hline Fluorapatite & 2 & $56.3 \pm 1.5$ & $0.5 \pm 0.3$ & $0.2 \pm 0.0$ & nd & nd & nd & $21.8 \pm 0.1$ & $0.3 \pm 0.0$ & $1.4 \pm 0.0$ & $80.7 \pm 1.1$ \\
\hline $\mathrm{Fe}(\mathrm{OH})_{3}$ forms with $\mathrm{P}$ & 2 & $0.2 \pm 0.0$ & $0.1 \pm 0.0$ & $0.2 \pm 0.2$ & $0.2 \pm 0.1$ & $5.7 \pm 1.8$ & $1.8 \pm 1.0$ & $6.0 \pm 2.2$ & $67.7 \pm 5.5$ & nd & $81.9 \pm 3.7$ \\
\hline Al-silicate (P-Fe-Mg) & 11 & $0.4 \pm 0.2$ & $6.4 \pm 0.6$ & $0.4 \pm 0.2$ & $1.4 \pm 0.1$ & $32.8 \pm 5.5$ & $14.9 \pm 0.0$ & $4.1 \pm 1.6$ & $14.2 \pm 2.0$ & nd & $74.9 \pm 0.8$ \\
\hline \multicolumn{12}{|c|}{ Pedon 15 - Ornithogenic (Anthropic) Haploturbels } \\
\hline Plagioclase with Fe-Mg & 1 & 8.5 & 4.8 & 2.4 & 2.0 & 50.9 & 17.5 & nd & 10.4 & nd & 99.0 \\
\hline Ca-plagioclase with Fe & 3 & $22.8 \pm 0.4$ & $0.1 \pm 0.0$ & $0.0 \pm 0.0$ & $0.0 \pm 0.1$ & $39.3 \pm 0.5$ & $25.0 \pm 1.0$ & nd & $9.8 \pm 0.4$ & nd & $97.4 \pm 1.4$ \\
\hline Ca-Na-Plagioclase & 3 & $12.5 \pm 2.2$ & $0.1 \pm 0.0$ & $4.4 \pm 1.3$ & $0.2 \pm 0.1$ & $54.4 \pm 2.6$ & $29.8 \pm 1.8$ & nd & $0.9 \pm 0.1$ & nd & $102.4 \pm 0.2$ \\
\hline $\mathrm{Fe}(\mathrm{OH})_{3}$ form* & 1 & 1.4 & 1.1 & 0.3 & nd & 31.8 & 8.0 & 1.0 & 54.6 & & 98.2 \\
\hline $\mathrm{Fe}(\mathrm{OH})_{3}$ form ${ }^{* *}$ & 18 & $0.2 \pm 0.0$ & $0.0 \pm 0.0$ & $0.0 \pm 0.0$ & nd & $0.2 \pm 0.1$ & $0.4 \pm 0.2$ & $1.8 \pm 0.2$ & $89.5 \pm 2.2$ & nd & $92.3 \pm 2.3$ \\
\hline $\mathrm{Fe}(\mathrm{OH})_{3}$ form $* * *$ & 1 & 0.1 & 0.0 & nd & nd & 1.0 & nd & 0.6 & 96.9 & nd & 98.7 \\
\hline Al-silicate (Na-Fe) & 2 & $0.4 \pm 0.1$ & $1.3 \pm 0.5$ & $4.4 \pm 0.9$ & $1.3 \pm 0.4$ & $45.3 \pm 4.9$ & $11.8 \pm 4.7$ & $0.7 \pm 0.6$ & $23.0 \pm 6.9$ & $0.1 \pm 0.0$ & $88.3 \pm 4.5$ \\
\hline
\end{tabular}

$n$ : number of analysis; nd: not determined. Sequence: *soil matrix near $\mathrm{Fe}(\mathrm{OH})_{3}$ form; ${ }^{* *} \mathrm{Fe}(\mathrm{OH})_{3}$ form's edge; ${ }^{* * *}$ inside $\mathrm{Fe}(\mathrm{OH})_{3}$ form. 


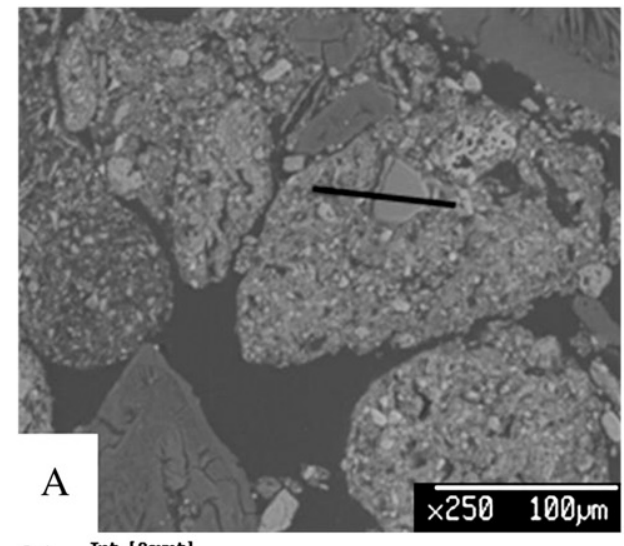

Si

Int [ Count]

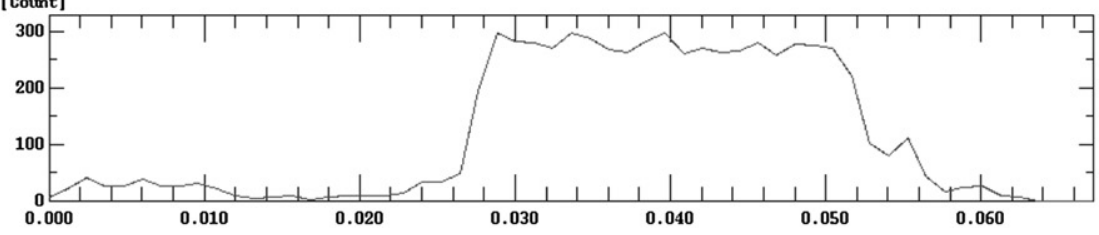

Al

Int [Count]

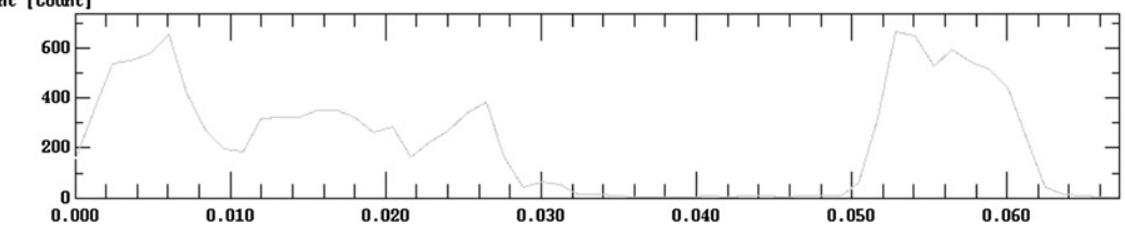

Ca

Int [ Coupt]

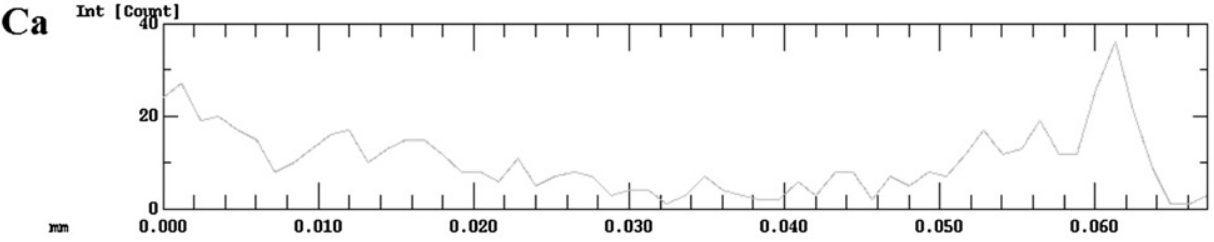

$\mathbf{P}$

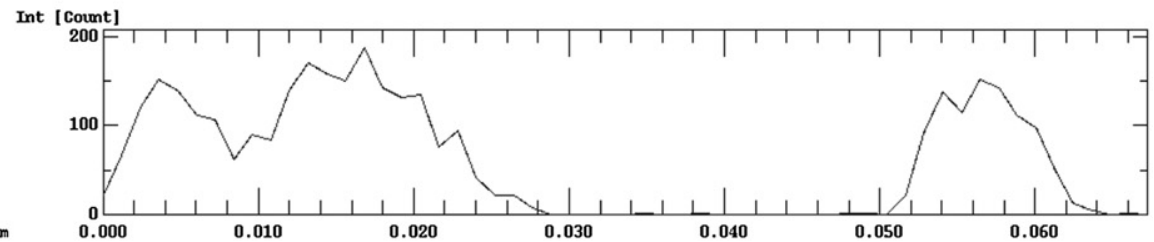

Mg

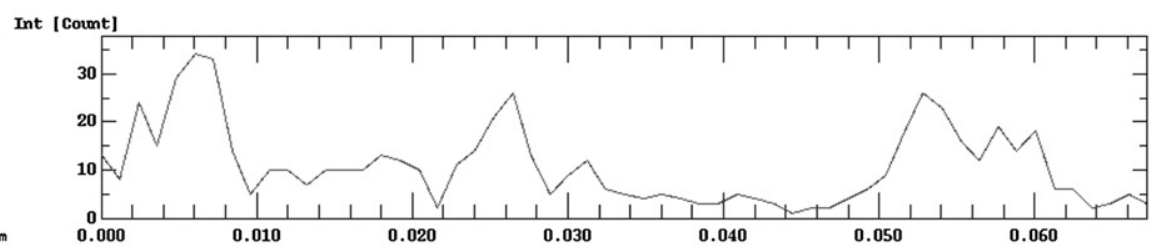

$\mathrm{Fe}$

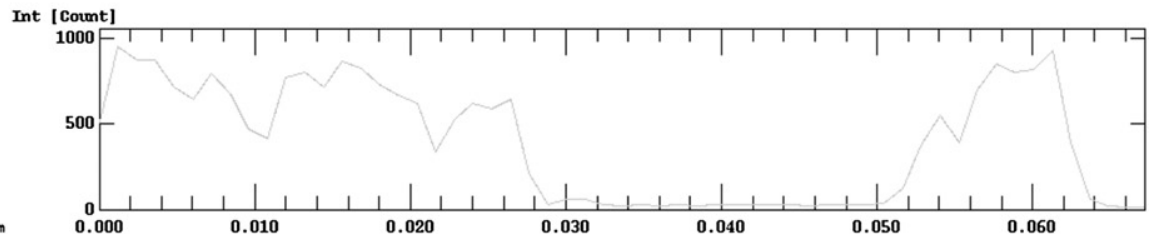

K

Int [Count]

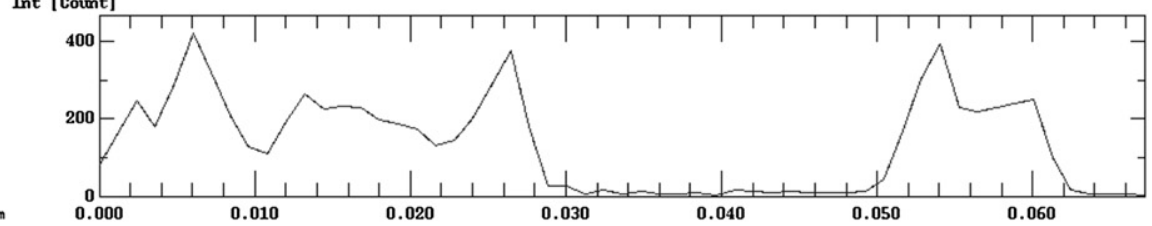

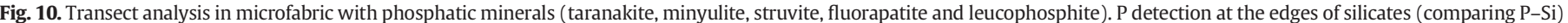
can indicate reaction due chemical attack (pedon 15). Black line in image A show where transect was performed. 


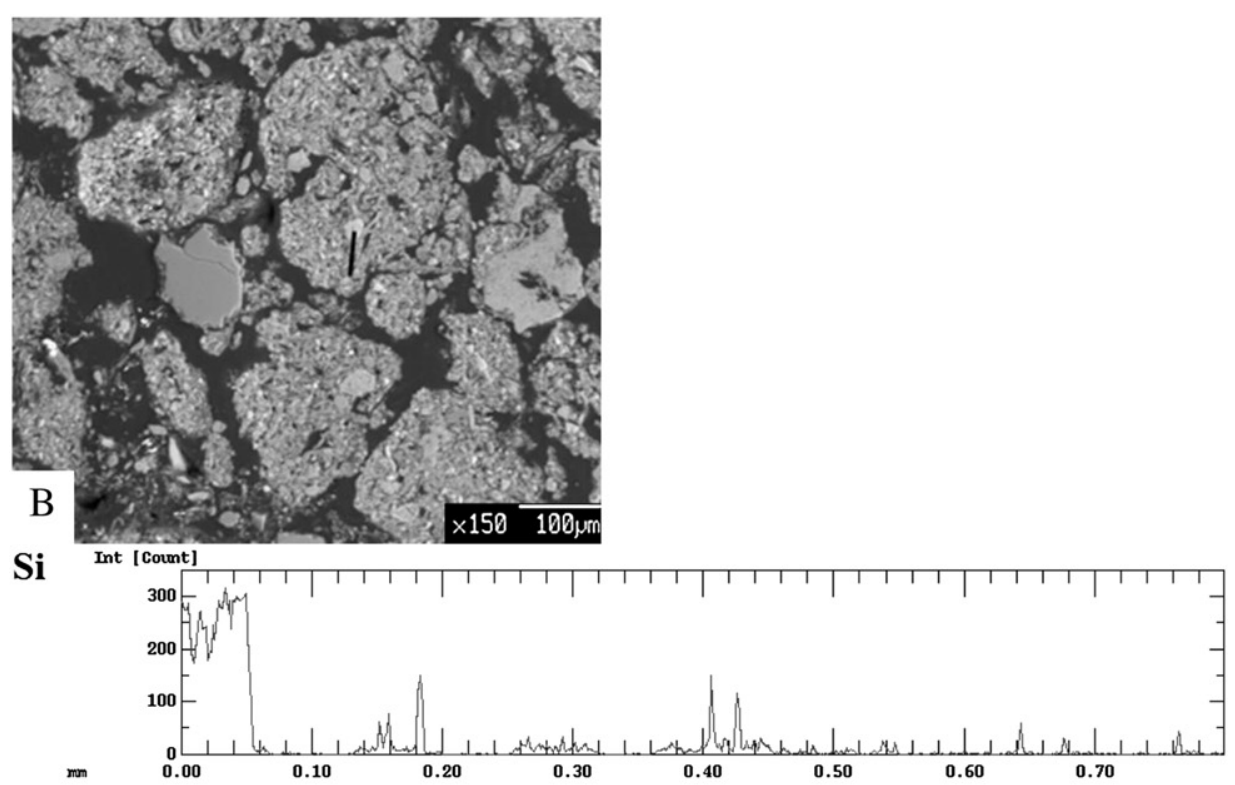

Al

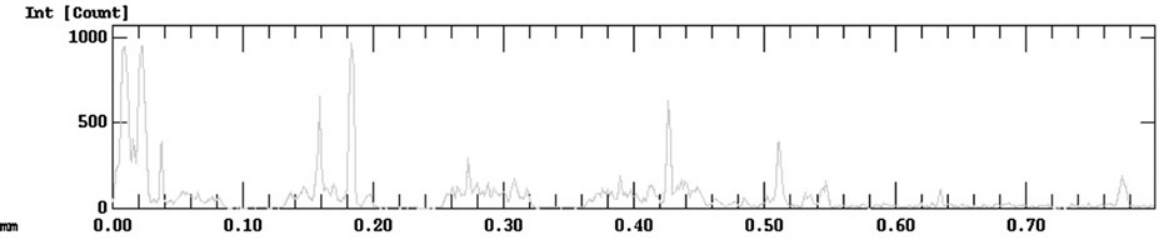

Ca

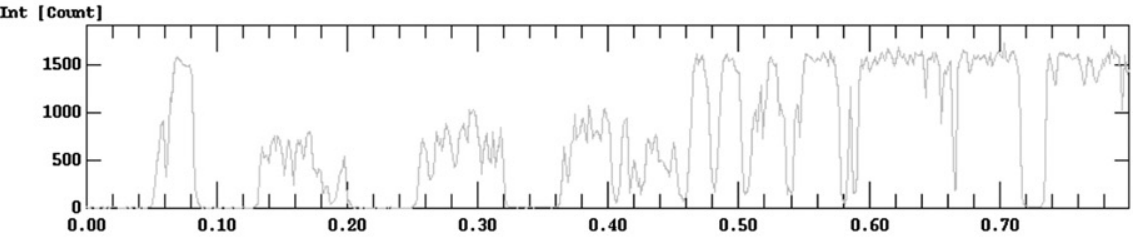

Int [ Count]

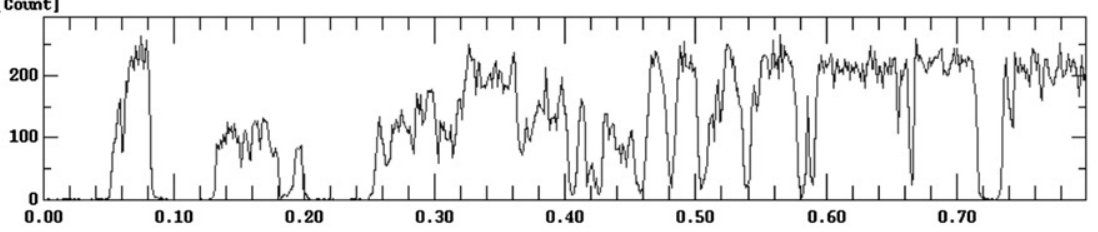

Mg

Int [Coumt]

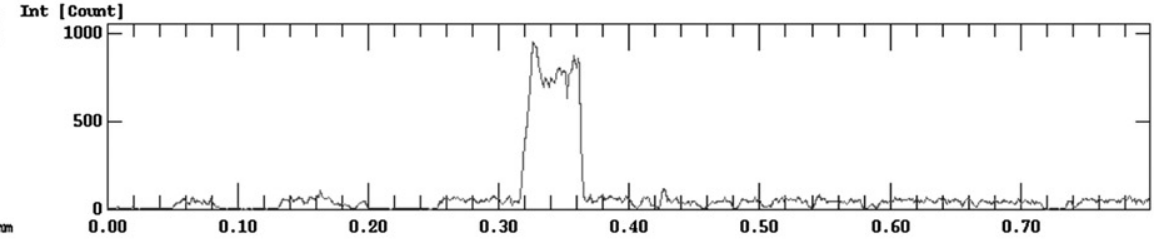

$\mathbf{F e}$

Int [count]

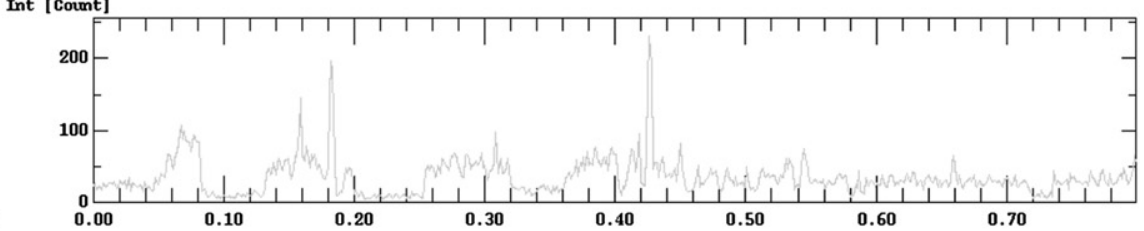

$\mathbf{K}$

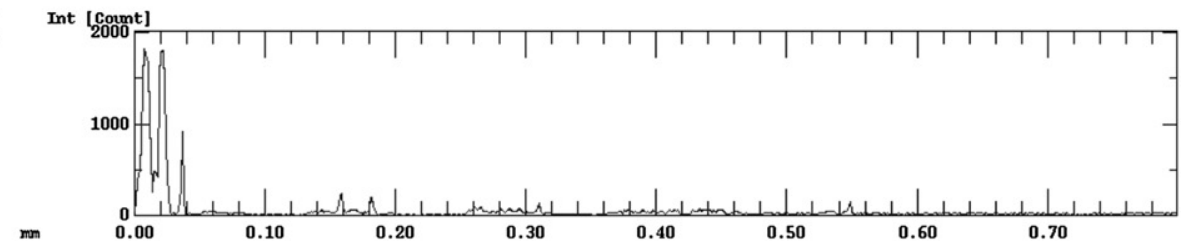

Fig. 11. Transect analysis in soil matrix with fluorapatite and struvite (pedon 17). Black line in image B show where transect was performed. 


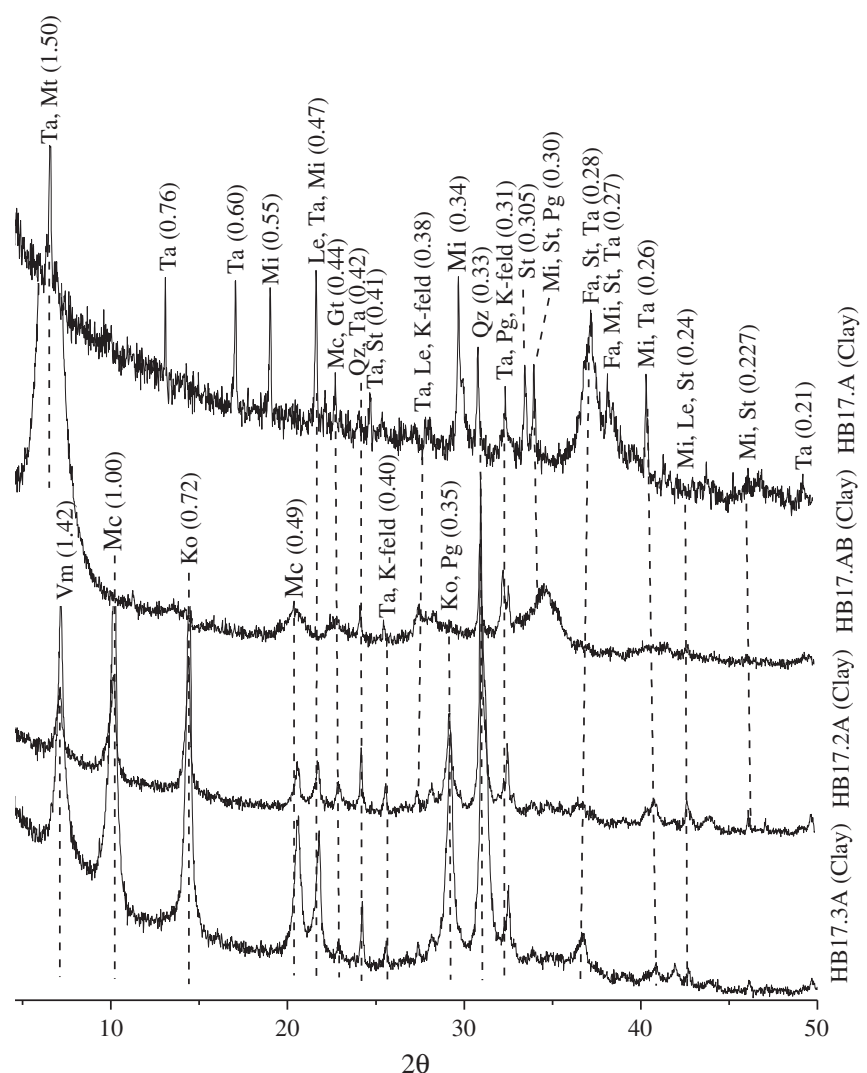

Fig. 12. XRD patterns for the ornithogenic soils at Hope Bay, Antarctic Peninsula. Pedon HB17. Mt - montmorillonite, Vm - vermiculite, Mc - mica, Ta - taranakite, Le leucophosphite, Mi - minyulite, St - struvite, Fa - fluorapatite, Ko - kaolinite, Gt goethite, Qz - quartz, K-Feld - K-feldspar, and Pg - plagioclase. “d” in nm.

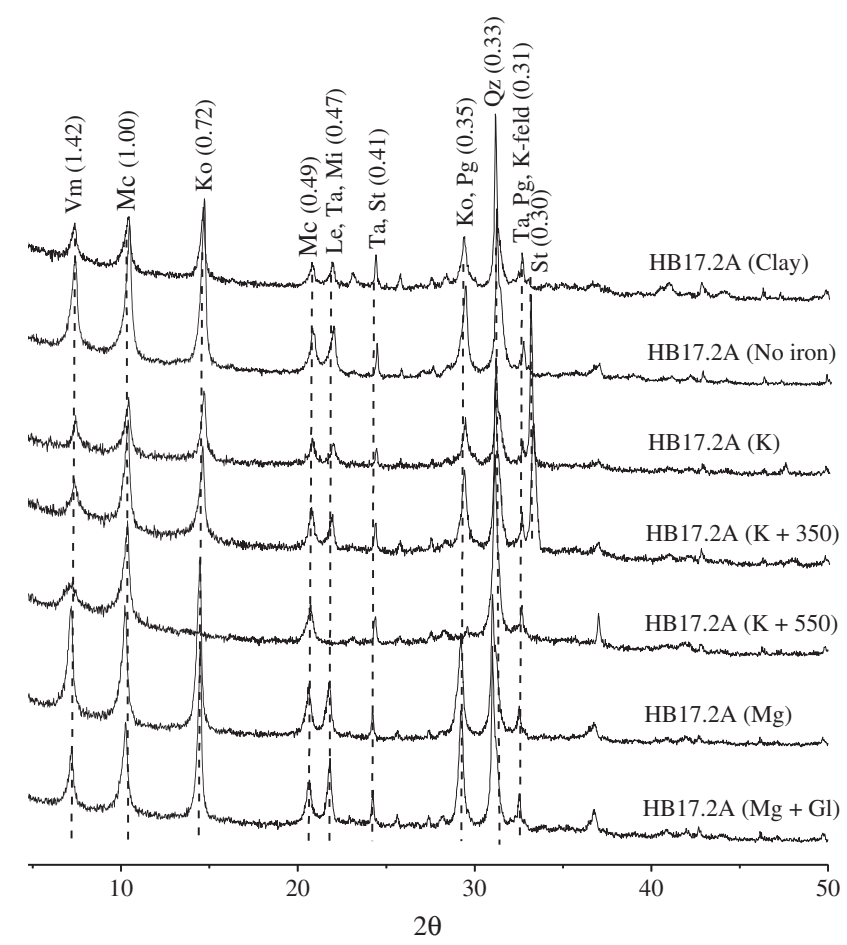

Fig. 13. XRD patterns for the ornithogenic soils at Hope Bay, Antarctic Peninsula (pedon 17 treatments). Vm - vermiculite, Mc - mica, Ta - taranakite, Le - leucophosphite, Mi minyulite, St - struvite, Ko - kaolinite, Qz - quartz, K-Feld - K-feldspar, and Pg plagioclase. "d" in nm.
Another factor which indicates that warmer conditions occurred in the past is the permafrost cementation of deeper phosphate layers. During these warmer periods, $\mathrm{P}$ was leached downwards and strongly reacted with the rock substrates.

\section{Conclusions}

The soils of Antarctic Peninsula have a moderate to strong microstructural development. A small to medium-sized granular structure is generally observed, with rounded to subrounded forms, including several well-defined ornithogenic materials, such as P-rich organic remains, nodular phosphates forms and minute fragments of bone apatite.

The microstructure is typically orbiculic, ovoidal-shaped, consistent with that is described for cryogenic fabrics of Antarctic Cryosols from elsewhere. These materials are usually surrounded by concentric illuvial deposition of phosphates indicating a phosphatization soil-forming process.

In the fine matrix, the chemical composition of some sections indicates the presence of discrete phases of taranakite, minyulite, leucophosphite, struvite, and fluorapatite, typical of phosphatization process in ornithogenic soils. In the sand-sized fraction, plagioclases and quartz occur.

Permafrost cementation of deeper phosphate layers indicate that warmer conditions occurred in the past, during which phosphate was leached downwards and reacted with the rock substrates. The occurrence of kaolinite and goethite may be related to these conditions.

The phosphatization process enhances chemical alteration of the substrate and is one of the main soil-forming processes in ornithogenic soils.

Chemical weathering is much more pronounced than previously thought for Antarctic Peninsula, especially for ornithogenic soils under cold climates.

The application of micromorphological and microchemical techniques proved to be extremely useful for a better understanding of pedogenesis in these poorly known Antarctic soils.

\section{Acknowledgments}

T. Pereira and C. Schaefer acknowledge the Brazilian CAPES agency and Brazilian National Research and Technology Council (CNPq) for financing this research. Thanks are due to the Brazilian Navy for the logistics during the Antarctic expeditions. A special acknowledgment is made to the staff of the Center of Microscopy and Microanalysis and Center of Geographical Studies of the University of Lisbon for their support during the SEM/WDS analysis. This is a contribution of INCT of Cryosphere (CNPq).

\section{References}

Birkenmajer, K., 1993a. Jurassic terrestrial clastics (Mount Flora Formation) at Hope Bay, Trinity Peninsula (West Antarctica). Bulletin of the Polish Academy of Sciences: Earth Sciences 41, 23-38.

Birkenmajer, K., 1993b. Geology of late Mesozoic magmatic rocks at Hope Bay, Trinity Peninsula (West Antarctica). Bulletin of the Polish Academy of Sciences: Earth Sciences 41, 49-62.

Bisdom, E.B.A., Ducloux, J., 1983. Submicroscopic studies of soils. Developments in Soil Science, 12. Elsevier, Amsterdam (356 pp.).

Blume, H.P., Chen, J., Kalk, E., Kuhn, D., 2004. Mineralogy and weathering of Antarctic Cryosols. In: Kimble, J. (Ed.), Cryosols - Permafrost Affected Soils. Springer-Verlag, Berlin, pp. 415-426.

Brewer, R., 1964. Fabric and Mineral Analysis of Soils. Robert E. Krieger Publications Co., Huntington, New York.

Bullock, P., Fedoroff, N., Jongerius, A., Stoops, G., Tursina, T.E., Babel, U., 1985. Handbook for Thin Section Description. WAINE Research Publications, Albrighton, Wolverhampton, U.K.

del Valle, R.A., Morelli, J.R., Rinaldi, C.A., 2001. Geology of new localities on Tabarin Peninsula, northern Antarctic Peninsula. Antarctic Science 13, 323-328.

FitzPatrick, E.A., 1956. An indurated soil horizon formed by permafrost. Journal of Soil Science 7, 248-257.

Fox, C.A., Protz, R., 1981. Definition of fabric distributions to characterize the rearrangement of soil particles in Turbic Cryosols. Canadian Journal of Soil Science $61,29-34$.

Kubiena, W., 1970. Micromorphology of polygenetic soils and paleosols in polar regions. Annales de Edafologia y Agrobiologia, pp. 845-856. 
Martín-Serrano, A., Montes, M., Nozal, F., del Valle, R.A., 2005. Geomorfología de la costa austral de Bahía Esperanza (Península Antártica). Geogaceta 38, 95-98.

Michel, R.F.M., Schaefer, C.E.G.R., Dias, L., Simas, F.N.B., Benites, V., Mendonça, E.S., 2006. Ornithogenic Gelisols (Cryosols) from Maritime Antarctica: pedogenesis, vegetation and carbon studies. Soil Science Society of America Journal 70, 1370-1376.

Pereira, T.T.C., Schaefer, C.E.G.R., Ker, J.C., Almeida, C.C., Almeida, I.C.C, Pereira, A.B. Genesis, in press. mineralogy and ecological significance of ornithogenic soils from a semi-desert polar landscape at Hope Bay, Antarctic Peninsula. Geoderma.

Schaefer, C.E.G.R., Simas, F.N.B., Albuquerque-Filho, M.R., Michel, R.F.M., Viana, J.H.M., Tatur, A., 2004. Fosfatização: Processo de formação de solos na Baía do Almirantado e implicações ambientais. In: Schaefer, C.E.G.R., Francelino, M.R., Simas, F.N.B. Albuquerque-Filho, M.R. (Eds.), Ecossistemas Costeiros e Monitoramento Ambiental da Antártica Marítima, Baía do Almirantado, Ilha Rei George. NEPUT - Dep. de Solos, Viçosa, pp. 47-59.

Schaefer, C.E.G.R., Simas, F.N.B., Gilkes, R.J., Mathison, C., Costa, L.M., Albuquerque, M.A., 2008. Micromorphology and microchemistry of selected Cryosols from Maritime Antarctica. Geoderma 144, 104-115.

Scientific Committee on Antarctic Research, 2002. Management Plan for Antarctic Specially Protected Area No. 148. Mount Flora, Hope Bay, Antarctic Peninsula. CEP draft.

Simas, F.N.B., Schaefer, C.E.G.R., Melo, V.F., Guerra, M.B.B., Saunders, M., Gilkes, R.J. 2006. Clay-sized minerals in permafrost-affected soils (Cryosols) from King George Island, Antarctica. Clays and Clay Minerals 54, 721-736.

Simas, F.N.B., Schaefer, C.E.G.R., Melo, V.F., Albuquerque-Filho, M.R., Michel, R.F.M., Pereira, V.V., Gomes, M.R.M., Costa, L.M., 2007. Ornithogenic Cryosols from Maritime Antarctica: phosphatization as a soil forming process. Geoderma 138, 191-203.
Smith, C.A.S., Fox, C.A., Hargrave, A.E., 1991. Development of soil structure in some Turbic Cryosols in the Canadian Low Arctic. Canadian Journal of Soil Science 71, 11-29.

Stoops, G., Jongerius, A., 1977. Proposals for a micromorphological classification of soil materials. I. A classification of related distribution of coarse and fine particles. A reply. Geoderma 19, 247-249.

Tarnocai, C., Valentine, R., 1989. Relict soil properties of the Arctic and Subarctic regions of Canada. Catena (Suppl. 16), 9-39.

Tarnocai, C., Smith, C. A. Fox, C. . 1993. International tour of permafrost affected soils - the Yukon and Northwestern territories of Canada. Centre for Land and Biol. Resources Res., Res. Branch, Ag. Canada. (197 pp.).

Tatur, A., 1989. Ornithogenic soils of the Maritime Antarctic. Polish Polar Research 4 481-532.

Tatur, A., Barczuk, A., 1985. Ornithogenic phosphates on King George Island, Maritime Antarctic. In: Siegfried, W.R., Condy, P.R., Laws, R.M. (Eds.), Antarctic Nutrien Cycles and Food Webs. Springer-Verlag, Berlin, pp. 163-169.

Tatur, A., Keck, A., 1990. Phosphates in ornithogenic soils of the Maritime Antarctic. Proc. NIPR Symp. Polar Biol., 3, pp. 133-150.

van Vliet-Lanöe, B., 1985. Frost effect in soils. In: Boardman, J. (Ed.), Soils and Quaternary Landscape Evolution. Wiley Publ., London, pp. 117-158.

van Vliet-Lanöe, B., Fox, C.A., Gubin, S.V., 2004. Micromorphology of Cryosols. In Kimble, J. (Ed.), Cryosols - Permafrost-Affected Soils. Springer-Verlag, Berlin, pp. 365-391.

White, T.L., Fox, C.A., 1997. Comparison of cryogenic features dominant in permafrost affected soils with those produced experimentally. In: Shoba, S., Gerasimova, M. Miedema, R. (Eds.), Soil Micromorphology: Studies on Soil Diversity, Diagnostic and Dynamics: Proceeding of the X International Working Meeting on Soil Micromorphology, Moscow, Russia. 